\title{
UVODNIK
}

\section{SEDANJOST IN PRIHODNOST VISOKOŠOLSKEGA IZOBRAŽEVANJA}

Tokratna številka Andragoških spoznanj je nastala kot rezultat projekta Inovativno učenje in poučevanje $v$ visokem šolstvu (INOVUP), ki se izvaja na vseh treh javnih slovenskih univerzah: Univerzi v Ljubljani, Univerzi v Mariboru in Univerzi na Primorskem. Poleg teh treh institucij, ki zajemajo večino slovenskega visokošolskega prostora, v konzorciju sodeluje tudi Fakulteta za informacijske študije v Novem mestu. Osrednji namen projekta INOVUP (www.inovup.si), ki ga financira ministrstvo za izobraževanje, znanost in šport prek sredstev Evropskega socialnega sklada (ESS), je preveriti in »prevetriti« visokošolsko didaktiko na slovenskih univerzah. V projektu ne želimo zgolj analizirati stanja na tem področju, temveč prek različnih usposabljanj spodbuditi refleksijo visokošolskih učiteljev o lastni praksi in jih usposobiti za vpeljavo novih pristopov v poučevanje. Izhodišče projekta je torej v spoznanju, da mora biti visokošolski učitelj ne samo vrhunski znanstvenik na habilitiranem področju, temveč tudi didaktični strokovnjak, ki poleg drugih vidikov svojega dela razvija in spremlja tudi kakovost poučevanja.

Tovrstna prizadevanja projekta INOVUP na področju visokošolskega izobraževanja niso nekaj novega. Lahko bi rekli, da sega interes za raziskovanje značilnosti poučevanja in učenja na visokošolski ravni že vsaj v osemdeseta leta, ki jih označuje monografija Learning, Cognition, and College Teaching (McKeachie, 1980). Urednik te publikacije Walter McKeachie (1980) je v njej naštel tri glavna področja, ki so (vsaj z vidika pedagoške psihologije) pomembna za razumevanje poučevanja in učenja $v$ visokem šolstvu in so še vedno aktualna: poznavanje kognitivnih procesov, učnih metod in razlik med študenti. V našem prostoru smo bili na tem področju tudi takrat že v koraku s časom, saj sta se prof. dr. Vlado Schmidt (1972) in prof. ddr. Barica Marentič Požarnik (1978) že v sedemdesetih letih ukvarjala tudi z vprašanji visokošolske didaktike. Razmisleke o kakovosti in rezultatih visokošolskega poučevanja pa lahko odkrijemo tudi že prej, npr. Klapper (1950) je že v petdesetih letih prejšnjega stoletja pisal o razhajanjih med postavljenimi učnimi cilji predmeta in dejanskimi dosežki študentov ter pozival $\mathrm{k}$ temu, da bi tudi visokošolski učitelji obvezno potrebovali vsaj minimalna znanja s področja poučevanja. Ideje, o katerih na različnih visokošolskih posvetih razpravljamo še danes.

S čim se univerza in visokošolski učitelj soočata danes? Kot poudarja Aoun (2017), vstopamo v 21. stoletje, ki ga spremljata četrta industrijska revolucija in avtomatizacija. Tudi 
v izobraževanju se tem spremembam ne moremo izogniti, še najmanj na visokošolski ravni. Aoun meni, da bi morali predvsem v visokošolskem izobraževanju v tem obdobju četrte industrijske revolucije oblikovati izobraževalne modele, ki bi razvijali zlasti tisto znanje in spretnosti, ki bodo v prihodnosti nenadomestljivi z algoritmi ali roboti: kreativnost, kritično mišljenje, nove pismenosti (digitalno in druge), multikulturnost in podjetnost (Aoun, 2017). Glavne značilnosti univerze prihodnosti torej niso toliko povezane s tehnološko infrastrukturo ali celo zaposljivostjo kot z bolj »razsvetljenskimi« cilji univerzitetnega študija.

Ob tem se seveda postavlja vprašanje, kako naj te cilje v visokošolskem izobraževanju dosežemo. Ali so obstoječi načini dovolj dobri ali bi jih bilo treba izboljšati? V projektu INOVUP univerze sledijo spoznanjem pedagoške in psihološke stroke, po katerih je uspešnost študija sicer odvisna od mnogih dejavnikov, eden pomembnejših pa je kakovost pedagoškega dela učiteljev, asistentov, lektorjev in drugih, ki izvajajo pedagoški proces. Kakovost pedagoškega dela je težko definirati, še težje meriti, nedvomno pa je povezana tudi z ustrezno didaktično usposobljenostjo pedagoškega kadra. Sama »inovativnost « učnih metod tukaj ni toliko pomembna kot uporaba ustreznih metod za doseganje določenih učnih ciljev oziroma razvoj v učnem načrtu zapisanih kompetenc. Ali lahko vse dosežemo samo z uporabo ene metode? Težko. Ali je samo zaradi uporabe tako imenovanih inovativnih učnih metod študij kaj bolj kakovosten? Prav tako ne. Izbira učnih metod je preplet različnih učiteljevih odločitev, ki so pogojene s cilji, vsebino, študenti ali okoliščinami, v katerih poteka študij.

Martin, Prosser, Trigwell, Ramsden in Benjamin (2000) menijo, da na različne stile poučevanja ne vpliva toliko učiteljeva strokovnost ali pedagoško (didaktično) znanje, temveč tudi to, kakšno znanje želi študentom posredovati in kako (s katerimi učnimi metodami/ oblikami) namerava to doseči. V zgodovini visokošolske didaktike so potekale že številne debate, kateri pristopi so najbolj učinkoviti. Velik del razprav se je vrtel ravno okoli empiričnih dokazov, ki bi potrjevali ali zavrnili učinkovitost učnih metod, usmerjenih na študenta, v primerjavi z učnimi metodami, usmerjenimi na vsebino/učitelja. Čeprav so rezultati v preteklosti kazali različne vplive teh dveh pristopov (npr. Krumboltz in Farquhar, 1957; Webb in Baird, 1968), pa si je danes stroka bolj ali manj enotna o prednosti uporabe visokošolskih učnih metod, ki spodbujajo aktivno udeležbo študentov pri učenju. Opravljene metaanalize v zadnjem obdobju so to stališče večkrat potrdile (Chen in Yang, 2019; Cornelius-White, 2007; Deslauriers, Schelew in Wieman, 2011; Schmidt, van der Molen, te Winkel in Wijnen, 2009).

Glede na to ni presenetljivo, da se poskuša v projektu INOVUP spodbuditi visokošolske učitelje k »inoviranju « lastne pedagoške prakse. Razvijati nove pristope, izboljšati obstoječe, predvsem pa deliti svoje izkušnje s kolegi in s tem spodbuditi razvoj skupnosti, ki bi lahko delovala tudi potem, ko se bo projekt končal. Seveda je jasno, da samo s prenovo izvedbe študijskega procesa ne bo mogoče trajno izboljšati kakovosti študija. To je še posebej pomembno, če imamo v mislih aktivne metode dela s študenti - te običajno potekajo v manjših skupinah, $\mathrm{v}$ didaktično dobro opremljenih predavalnicah in $\mathrm{z}$ učitelji, ki 
imajo dobre pogoje za svoj profesionalni razvoj. Izzivi za razvoj in ohranjanje kakovosti visokošolskega študija bodo torej po končanem projektu INOVUP za univerze celo večji, kot so zdaj.

Tokratna (tematska) številka Andragoških spoznanj prinaša šest zanimivih prispevkov s področja visokošolske didaktike.

Barica Marentič Požarnik v uvodnem prispevku Visokošolska didaktika in didaktično usposabljanje visokošolskih učiteljev pri nas - dosedanji razvoj, izkušnje in problemi opisuje spreminjanje pedagoških pristopov v visokošolskem izobraževanju od šestdesetih let do danes. Avtorica ob tem poudarja, da prizadevanje za izboljšanje procesov poučevanja v tem prostoru ni novo, temveč ima že dolgo tradicijo. V prispevku predstavlja glavne oblike, cilje, vsebine in metode ter dosežke didaktičnega usposabljanja visokošolskih učiteljev v različnih obdobjih.

Drugi prispevek z naslovom Spodbujanje aktivnega študija, kot ga zaznavajo študenti so pripravile Katja Košir, Tina Vršnik Perše, Sabina Ograjšek in Milena Ivanuš Grmek. V njem raziskujejo pomen koncepta »na študenta usmerjenega poučevanja «, ki temelji na spodbujanju študentove aktivne vloge v procesu lastnega učenja. Avtorice poudarjajo, da je za uspešno spodbujanje tega procesa treba razumeti učni proces študentov. V članku predstavljajo raziskavo, ki se je ukvarjala ravno s tem vprašanjem - zaznavanje visokošolskega pouka $\mathrm{z}$ vidika aktivnega osmišljanja študijskih vsebin in vidika povezovanja teoretičnih spoznanj s prakso.

V prispevku Možnosti za uporabo na študenta osredinjenih metod poučevanja in učenja bioloških predmetov na UP FAMNIT avtorici Živa Fišer in Alenka Baruca Arbeiter analizirata izvajanje bioloških predmetov z vidika na študenta osredinjenih pristopov učenja in poučevanja, podprtih z orodji informacijsko-komunikacijske tehnologije. Avtorici predstavljata raziskavo, s katero sta želeli odkriti učne metode, ki jih uporabljajo izvajalci praktičnega pouka bioloških predmetov. Rezultati so pokazali, da uporabljeni pristopi anketirancev podpirajo in nadgrajujejo izkustveno učenje, da o univerzalnih pristopih ni mogoče govoriti ter da se visokošolski učitelji avtonomno odločajo o primernih pristopih glede na učno vsebino in postavljene učne cilje.

Concetta Tino se v prispevku Celostna interpretacija osebnih in spremljevalnih dejavnikov upiranja študentov pri aktivnem učenju in strategijah poučevanja prav tako ukvarja s pristopi, ki spodbujajo na študenta usmerjeno poučevanje. Kljub dokazanim pozitivnim učinkom teh pristopov pa se - tako opozarja avtorica - študenti na njihovo vpeljavo ne odzovejo vedno pozitivno. Določen delež študentov, poudarja, take pristope vedno zavrača. Razlogi za to so različni in segajo od subjektivnih do objektivnih dejavnikov. V članku avtorica ponuja nekaj praktičnih izhodišč za zmanjševanje odklonilnega odnosa. Kot glavni dejavnik priporoča vzpostavitev celovitega didaktičnega sistema, ki zajema vse dejavnike, ki potencialno vplivajo na negativna stališča študentov do določenih didaktičnih pristopov. 
V članku Profesionalni razvoj in pedagoško usposabljanje visokošolskega učitelja Maja Mezgec ponuja poglobljen vpogled v modele profesionalnega razvoja visokošolskih učiteljev tako z vidika dejavnikov, ki vplivajo na ta profesionalni razvoj, kot z vidika njegovih faz. Posebno pozornost namenja vplivu usposabljanja ob delu ter pregledu področij kompetentnosti. Avtorica v prvem delu usmerja pozornost na doktorski študij, ki po njenem mnenju pomeni izhodišče kariernega in profesionalnega razvoja visokošolskega učitelja, v nadaljevanju pa se usmeri na dejavnike, ki spodbujajo nadaljnje izobraževanje in usposabljanje visokošolskih učiteljev.

Monika Govekar-Okoliš in Nataša Kermavnar v prispevku Mentorstvo medicinskih sester in njihovi pogledi na učinkovitost prakse univerzitetnih študentov predstavljata vidike, ki vplivajo na učinkovitost mentorstva za študente zdravstvene nege v bolnišnicah. Namen študije je bil ugotoviti učinke mentorstva medicinskih sester za študente med njihovo prakso in načine izboljšanja mentorstva $\mathrm{v}$ zdravstveni praksi študentov. Izsledki njune raziskave so nakazali na pomanjkljivo pedagoško in andragoško znanje mentorjev ter potrebo po vzpostaviti mednarodne mreže mentorstva medicinskih sester. To bi po njunem mnenju lahko imelo velik vpliv na mednarodno sodelovanje mentorjev medicinskih sester, učinkovitost njihovega mentorstva, boljšo zdravstveno prakso in zaposlovanje študentov.

V članku Bralno razumevanje strokovnih besedil v tujem jeziku: vloga strokovnega predznanja avtorica Alenka Umek obravnava vzorce, ki jih uporabljajo študenti ekonomskih in poslovnih ved $v$ procesu bralnega razumevanja strokovnih besedil v tujem jeziku. Avtorica je bralno razumevanje preverjala $\mathrm{z}$ metodo glasnega razmišljanja ob branju in ugotovila, da so bralci z boljšim strokovnim predznanjem pogosteje uporabili pravilno parafraziranje, sklepanje, pojasnjevanje in vrednotenje. Bralci s šibkejšim strokovnim predznanjem so pogosteje uporabili lokalni pristop k branju, s tem da so se bolj osredinili na posamezne besede. Pri tem so med rabo slovenskega jezika uporabljali angleške izraze ter nepravilne ali približne parafraze. Avtorica v sklepu študije ponuja tudi nekatere napotke za poučevanje branja v tujem jeziku in razvijanje disciplinarne pismenosti.

V rubriki »Poročila, odmevi, ocene« avtorice Monika Govekar-Okoliš, Katja Jeznik, Nina Breznikar in Klara Skubic Ermenc poročajo o Pedagoško-andragoških dnevih, ki so potekali 23. januarja 2020 na Filozofski fakulteti Univerze v Ljubljani. Številka se končuje z recenzijo knjige Doba velikih migracij na Slovenskem avtorjev Kalc, Milharčič Hladnik in Žitnik Serafin, ki jo je pripravila Klara Kožar Rosulnik.

Nastanek tokratne številke je zaznamovan tudi z boleznijo COVID-19, posledično samoizolacijo in tako rekoč prisilnim prehodom s klasičnega načina poučevanja na poučevanje in učenje na daljavo. Brutalen socialni in pedagoški eksperiment, ki pa je nedvomno lahko tudi povod za refleksijo naše pedagoške prakse. Uredništvo Andragoških spoznanj upa, da bomo kamenček k tej refleksiji prispevali tudi s to tematsko številko. 


\section{Financiranje}

Prispevek je rezultat raziskovalnega dela, sofinanciranega s strani Republike Slovenije in Evropske unije iz Evropskega socialnega sklada v okviru projekta Inovativno učenje in poučevanje v visokem šolstvu (INOVUP).

\section{LITERATURA}

Aoun, J. E. (2017). Robot-proof: Higher education in the age of artificial intelligence. Cambridge: MIT Press.

Chen, C.-H. in Yang, Y.-C. (2019). Revisiting the effects of project-based learning on students' academic achievement: A meta-analysis investigating moderators. Educational Research Review, 26, 71-81.

Cornelius-White, J. (2007). Learner-centered teacher-student relationships are effective: A meta-analysis. Review of Educational Research, 77(1), 113-143.

Deslauriers, L., Schelew, E. in Wieman, C. (2011). Improved Learning in a Large-Enrollment Physics Class. Science, 332(6031), 862-864.

Klapper, P. (1950). Problems in College Teaching. Bulletin of the American Association of University Professors, 36(1), 53-63.

Krumboltz, J. D. in Farquhar, W. W. (1957). The effect of three teaching methods on achievement and motivational and outcomes in a how-to-study course. Psychological Monographs: General and Applied, 71(14), 1-26.

Marentič Požarnik, B. (1978). Prispevek k visokošolski didaktiki. Ljubljana: Državna založba Slovenije.

Martin, E., Prosser, M., Trigwell, K., Ramsden, P. in Benjamin, J. (2000). What university teachers teach and how they teach it. Instructional Science, 28(5), 387-412.

McKeachie, W. J. (1980). Learning, Cognition, and College Teaching. San Francisco: Jossey-Bass Publishers.

Schmidt, H. G., van der Molen, H. T., te Winkel, W. W. R. in Wijnen, W. H. F. W. (2009). Constructivist, problem-based learning does work: A meta-analysis of curricular comparisons involving a single medical school. Educational Psychologist, 44(4), 227-249.

Schmidt, V. (1972). Visokošolska didaktika. Ljubljana: Državna založba Slovenije.

Webb, C. in Baird, J. H. (1968). Learning Differences Resulting from Teacher- and Student-Centered Teaching Methods. The Journal of Higher Education, 39(8), 456-460. 